DOE/EA - 1009

\title{
ENVIRONMENTAL ASSESSMENT FOR DOE PERMISSION FOR OFF-LOADING ACTIVITIES TO SUPPORT THE MOVEMENT OF COMMERCIAL LOW LEVEL NUCLEAR WASTE ACROSS THE SAVANNAH RIVER SITE
}

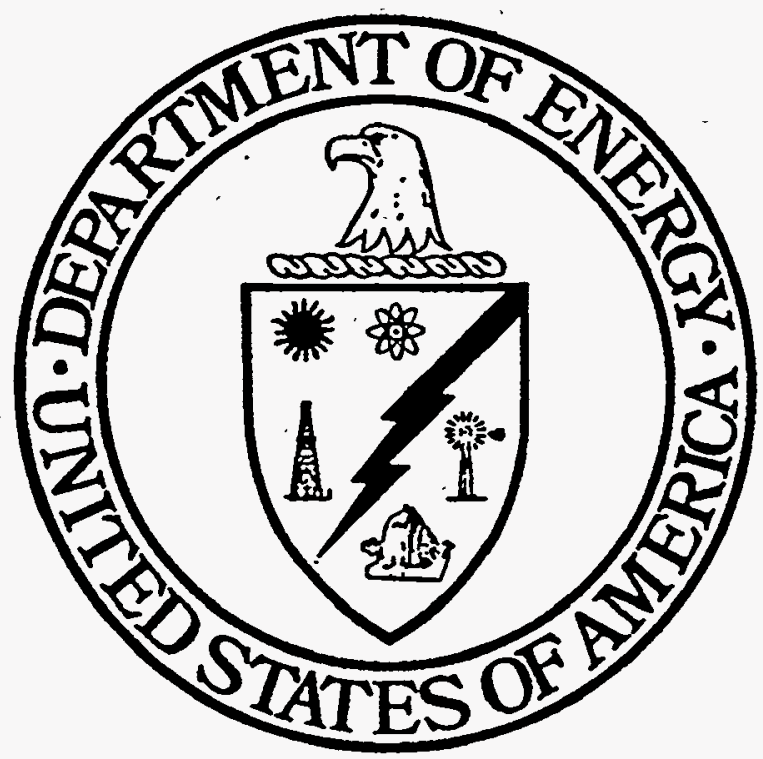

FEBRUARY 1995

UNITED STATES DEPARTMENT OF ENERGY SAVANNAH RIVER OPERATIONS OFFICE SAVANNAH RIVER SITE 


\section{DOE/EA - 1009}

\section{ENVIRONMENTAL ASSESSMENT FOR DOE PERMISSION FOR OFF-LOADING ACTIVITIES TO SUPPORT THE MOVEMENT OF COMMERCIAL LOW LEVEL NUCLEAR WASTE ACROSS THE SAVANNAH RIVER SITE}

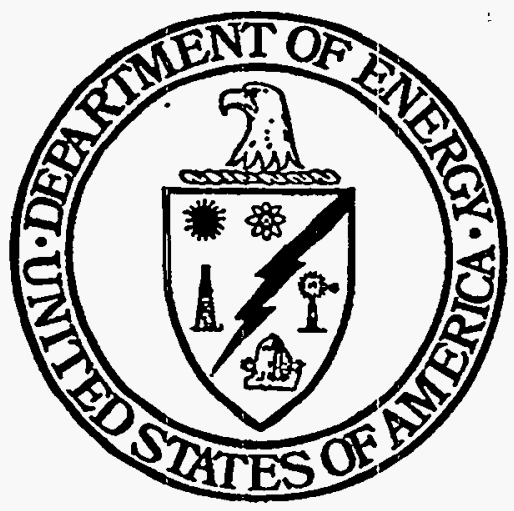

FEBRUARY 1995

\section{UNITED STATES DEPARTMENT OF ENERGY} SAVANNAH RIVER OPERATIONS OFFICE SAVANNAH RIVER SITE 


\section{DISCLAIMER}

Portions of this document may be illegible in electronic image products. Images are produced from the best available original document. 


\section{TABLE OF CONTENTS}

1.0 PURPOSE AND NEED FOR ACTION 1

2.0 PROPOSED ACTION AND ALTERNATTVES 1

2.1 Proposed Federal Action 2

2.2 Alternatives to the Proposed Federal Action . 2

2.2.1 Use of Other Docking Facilities 2

2.2.2 Overland Rail Movement 4

2.2.3 Overland Road Movement , 4

3.0 ENVIRONMENT CONSEQUENCES 4

4.0 SAFETY IMPACTS 5

4.1 Conventional Safety , 5

4.2 Nuclear Safety 6

5.0 REFERENCES 8

\section{LIST OF FIGURES}

Figure 1. Location of SRS Boat Ramp and Transport Routes

\section{APPENDIXES:}

Appendix A: Floodplain/Wetlands Assessment 


\subsection{NEED FOR ACTION}

Chem-Nuclear Systems Incorporated (CNSI) maintains and operates the low level radioactive waste burial facility adjacent to the Savannah River Site (SRS) in Barnwell County, South Carolina. As the operating contractor at the Barnwell Facility, CNSI has accepted an oversize/overweight package from the Charleston Naval Shipyard (CNSY) for disposal. The package would contain only dry, solid, low level radiologically contaminated waste. The contents of the sealed package would consist primarily of the radiologically contaminated portions of a service barge. The barge, commissioned by the United States Navy to service and maintain ships in its nuclear powered fleet, contained both administrative areas and radiologically controlled work areas. The barge has been in an inactive status since the 1960 s and is being decommissioned in a joint effort by CNSI and CNSY. CNSI will be responsible for the shipment of the package from CNSY to the CNSI facility. Currently the barge (herein after referred to as the "disposal package") is being prepared by shipyard personnel for transportation and disposal.

A transport barge carrying the disposal package would make landing at the existing SRS boat ramp, the ramp would be modified as needed for the off-loading, and then the disposal package would be off-loaded and shipped via SRS and state roadways to the CNSI facility.

This Environmental Assessment (EA) assesses the potential environmental and safety effects of the U.S. Department of Energy (DOE) allowing CNSI to use Federal property (SRS), for off-loading activities needed to support the movement of this oversize/overweight disposal package to the CNSI facility in Barnwell County, South Carolina.

Federal permission to use the SRS boat ramp is necessary to enable CNSI to ship the disposal package via waterborne traffic, the safest and most economical means of movement for this huge package. Once offloaded, the package would be shipped overland using CNSI equipment to its final destination in Barnwell County. The proposed action has no connection to SRS operations and is in no way necessary to support SRS activities.

\subsection{PROPOSED ACTION AND ALTERNATIVES}

The preparation of the decommissioned barge involves the removal of any materials within the radiologically controlled areas of the barge which have not been authorized for disposal by the South Carolina Department of Health and Environmental Controls (SCDHEC), particularly installed lead shielding. SCDHEC is the regulatory authority for the CNSI facility. In addition, the shipyard would drain waste processing system components of all liquids and remove non-radioactive structural components from the barge. Upon completion of preparation activities, the carbon steel bulkheads, overhead and deck, which form the boundaries of the radiological work area within the barge, would constitute the six sides of the disposal package. The thickness of the exterior sides of the package would range from 0.8 to $7.8 \mathrm{~cm}(0.3$ to $3.1 \mathrm{in})$.

The disposal package would measure approximately $21.9 \mathrm{~m}$ (l) $\times 3.81 \mathrm{~m}$ (h) $\times 8.25 \mathrm{~m}$ (w) [72'(l) $\times 12^{\prime}$ $\left.6 "(\mathrm{~h}) \times 27^{\prime} 1^{\prime \prime}(\mathrm{w})\right]$. Based upon these dimensions, the volume displacement of the package is $690.2 \mathrm{cu} \mathrm{m}$ $(24,372 \mathrm{cu} \mathrm{ft}$ ). The gross weight of the package would be between 235,868 and $272,155 \mathrm{~kg}$ (260 and 300 tons). The shipyard plans to package other low density, radiologically contaminated materials (generated from other decommissioning projects at the shipyard) within the disposal package void spaces. The final weight of the disposal package would be determined after this packaging evolution is completed and prior to shipment.

The isotopic composition of the waste would be within Type A quantity and Low Specific Activity (LSA) material limits. Once welded closed by the shipyard, the disposal package would meet Department of Transportation (DOT) requirements for a "strong tight container". The package would be shipped under the provisions of 49 CFR $173.425(\mathrm{~b})$. 
The disposal package would be loaded onto a specially designed trailer connected to large prime mover(s)/tow tractor(s) at the SRS boat ramp. This loading would be accomplished by backing the trailer underneath the disposal package while the package was positioned on wooden cribbing of the transport barge. The resulting truck-trailer combination would be approximately $34.1 \mathrm{~m}(\mathrm{l}) \times 8.25 \mathrm{~m}(\mathrm{w}) \times 4.72 \mathrm{~m}$ (h) $\left[112^{\prime}(\mathrm{l}) \times 27^{\prime} 1^{\prime \prime}(\mathrm{w}) \times 15^{\prime} 6^{\prime \prime}(\mathrm{h})\right]$ and would weigh $376,488 \mathrm{~kg}(830,000 \mathrm{lbs})$, assuming a package weight of $272,155 \mathrm{~kg}$ (300 tons).

\subsection{Proposed Federal Action}

The proposed Federal action is to allow CNSI to use Federal property for its transport barge to make landing at the existing SRS boat ramp, modify the ramp as needed for its off-loading, and off-load the disposal package for movement to the CNSI facility in Barnwell County. The existing SRS boat ramp was built in the 1950s. The CNSI modification activities at the SRS boat ramp are expected to be minimal in nature [removal of less than $18.4 \mathrm{cu} \mathrm{m}$ ( $24 \mathrm{cu}$ yds) of soil] and would be reviewed and approved by the U.S. Army Corps of Engineers (COE) as an action which is authorized under Nationwide Permit \#3, prior to any work being performed on the SRS boat ramp. More details are provided in Section 3.

According to CNSI plans, the disposal package would be shipped from CNSY on a $60.9 \mathrm{~m}(\mathrm{l}) \times 12.2 \mathrm{~m}(\mathrm{w})$ $\times 3.1 \mathrm{~m}(\mathrm{~h})\left[200^{\prime}(\mathrm{l}) \times 40^{\prime}(\mathrm{w}) \times 10^{\prime}(\mathrm{h})\right]$ transport barge which is designed to accommodate oversize/overweight loads. This same barge was used during CNSI's Millstone Steam Generator Project in 1992 and was landed twice at the SRS boat ramp in November and December of that year. This shipment from CNSY is proposed to begin in April 1995.

As specified by contract, all expenses associated with the proposed disposal package off-loading activities would be covered by CNSI. This includes all work at the SRS boat ramp, security, sediment sampling and disposal as necessary, mitigation actions required to return the ramp area to its former condition including erosion stabilization, movement of traffic signals and power lines, and any damages which could occur as a result of this movement, or the scheduling of this movement across SRS. CNSI would be liable for any accidents which could occur on SRS and all clean-up/repair activities which could result from such an accident.

SRS occupies about 80,267 hectares (ha) $(198,000$ acres) in southwestern South Carolina and is located 40 $\mathrm{km}$ (25 mi) miles southeast of Augusta, Georgia. The Savannah River Site boat ramp is located just north of the TNX Area on SRS and is surrounded by wooded areas (Figure 1). The TNX Area is an expanded testing area for the Savannah River Technology Center and contains simulated models and mock ups for SRS development activities. The SRS site contains national defense facilities including five nuclear production reactor areas; two chemical separations areas; waste processing, storage, and disposal facilities; and various supporting facilities.

\subsection{Altematives to the Proposed Federal Action}

The request by CNSI presents DOE with a decision involving two DOE alternatives; 1) allow the offloading activities (the proposed Federal action), or 2) refuse DOE permission (no action). Alternatives available to CNSI should DOE choose the no action alternative are discussed below.

\subsubsection{Use of Other Docking Facilities}

There is no other dock on the upper Savannah River on the South Carolina side which will accommodate oversize/overweight loads of this magnitude. The Georgia side facilities can not be used because the Savannah River bridges can not handle the weight. Therefore, other means of barge transport are not a reasonable alternative. 


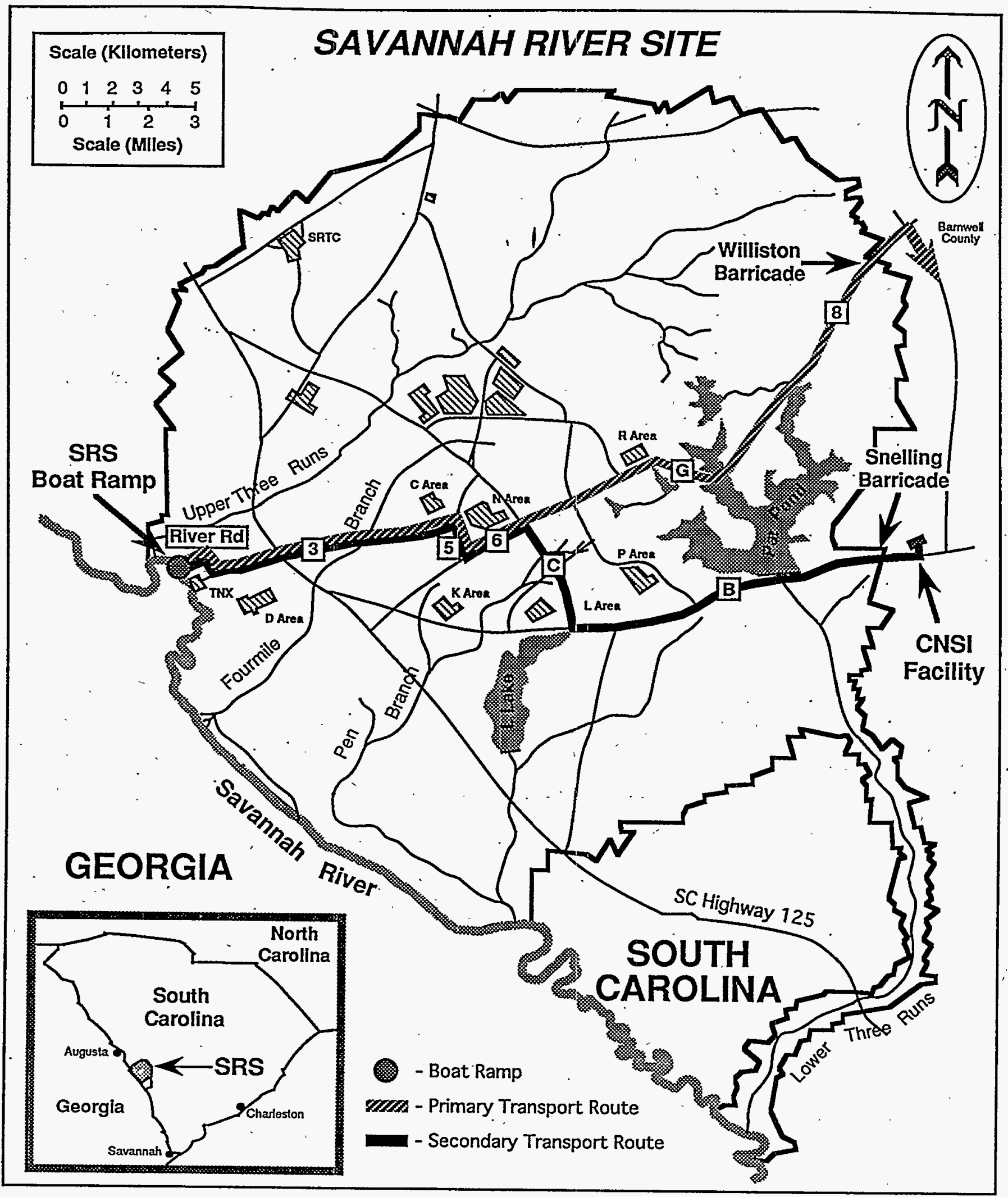

Figure 1. Location of SRS Boat Ramp and Transport Routes 


\subsubsection{Overland Rail Movement}

The width of the disposal package $8.26 \mathrm{~m}\left(27^{\prime} 1^{\prime \prime}\right)$ exceeds the legal width allowed for rail transport. Accordingly, this action was not considered as an acceptable alternative. This alternative was also disqualified from further consideration because many of the railroad bridges existing between Charleston and SRS have been found to be incapable of sustaining the weight of the disposal package. In addition, this means of movement would also represent an increased risk of accident. The chance of an accidental derailment is far greater than the possibility of a mishap by waterborne traffic.

\subsubsection{Overland Road Movement}

Another alternative to the proposed Federal action would be the movement of the disposal package from Charleston, South Carolina to Barnwell, South Carolina via overland highways. This is not considered as an acceptable alternative because of key highway bridges in route that cannot handle the $376,488 \mathrm{~kg}$ $(830,000 \mathrm{lbs})$ of weight and the many underpasses in route that are lower than $6.1 \mathrm{~m}(20 \mathrm{ft})$ [most interstate highway underpasses are designed for $4.3 \mathrm{~m}(14 \mathrm{ft})$ clearance]. Numerous low hanging power lines, phone lines, and traffic signals would make this mode of movement economically unfeasible. In addition to the physical obstacles which would have to be overcome, the movement would cause severe traffic obstacles at every point along its route.

In addition to the difficulties described above, this means of movement would also represent an increased risk of accident. The chance of a vehicular accident is far greater than the possibility of a mishap by rail or waterborne traffic. Accordingly, this alternative is not considered reasonable.

\subsection{ENVIRONMENTAL CONSEQUENCES}

The proposed off-loading activities that would take place on Federal land would be located at the SRS boat ramp on the Savannah River just upstream of SRS's TNX Area at river mile marker \#157. A recent Floodplain/Wetlands Assessment (see Appendix A) was conducted for the area surrounding the SRS boat ramp. This survey showed that the wetlands within the immediate area would not be affected by the offloading activities, providing that appropriate erosion control measures were implemented (Rogers, 1992).

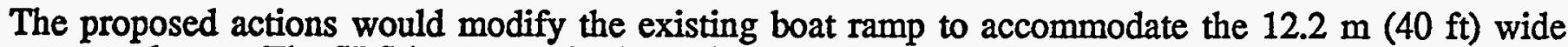
transport barge. The SRS boat ramp is shown in Figure 1. The CNSI modification activities at the SRS boat ramp are expected to be minimal in nature and would be reviewed and approved by the U.S. Army Corps of Engineers (COE) as an action which is authorized under Nationwide Permit \#3, prior to any work beginning on the SRS boat ramp. The modification activities would include dredging below the water line of the Savannah River on either side of the boat ramp skid plate.

In addition to the modification and environmental mitigation activities listed above, CNSI would also be responsible for returning the boat ramp above the ordinary high water mark to its preexisting condition. This would be accomplished by; initiating continuing erosion prevention and control activities; and reseeding/re-sodding the area surrounding the boat ramp.

CNSI estimates that no more than $18.4 \mathrm{cu} \mathrm{m}$ ( $24 \mathrm{cu} \mathrm{yds}$ ) of sediment would be dredged from the area $6.1 \mathrm{~m}$ $(20 \mathrm{ft}$ ) on either side of the center line of the SRS boat ramp. This figure may vary once actual dredging has begun, as it is strongly tied to the level of the river at the time of construction. In order to maintain compliance with the COE nationwide permit, CNSI has stated that in no case would more than $18.4 \mathrm{cu} \mathrm{m}$ ( 24 cu yds) of material be removed from below the Savannah River ordinary high water mark. CNSI would dispose of all sediments and debris, after monitoring and sampling for contamination as necessary, on SRS in an SRS erosion control pit. 
This Federal action would not threaten a violation of applicable laws or regulations; nor require major expansion or construction of waste facilities such as storage, treatment, or disposal facilities; nor release hazardous substances, pollutants, or contaminants into the environment. This action would take place at an area on the Savannah River previously developed in the 1950s and would not adversely affect environmentally sensitive resources such as historical or archaeological sites, endangered species or their habitat. In addition, an existing programmatic memorandum of agreement with the South Carolina State Historic Preservation Officer describes how SRS cultural resources are to be managed and assessed to determine National Register eligibility. Activities related to this Federal action comply with this agreement.

One potential impact associated with the proposed action would be the possible erosion which could occur as a result of the landing of the service barge and package off-loading operations. Accordingly, CNSI would abide by a Pollution Prevention Plan meeting SCDHEC requirements. These plans typically call for the use of siltation fences, erosion control tarpaulins, and re-seeding/re-sodding to mitigate and control any erosion or sediment run-off. The cumulative effects of these activities have been reviewed and it was determined that they would have no major impact on the surrounding environment (USN, 1984, DOE, 1992, \& Rogers, 1992).

The construction and operation of a barge landing slip (an action similar to the one proposed in this EA, but on a larger scale) was previously assessed for the SRS boat landing, which includes the boat ramp, in the Environmental Impact Statement for the Disposal of Decommissioned, Defueled Naval Submarine Reactor Plants (USN, 1984). The proposed action was specifically addressed under the Environmental Assessment for DOE Permission for Off-loading Activities to Support the Movement of Millstone Unit 2 Steam Generator Sub-Assemblies Across the Savannah River Site (DOE, 1992). The EIS and EA examined SRS and the area surrounding the SRS boat landing and ramp for impact on threatened and endangered species ${ }_{0}$ wetlands, and other environmentally sensitive resources and found that such actions as are discussed in this EA would have "Temporary and minor environmental impacts........". There has been no discernible change in the area surrounding the SRS boat ramp since the preparation of the EIS or EA sited above.

The Final Supplemental Environmental Impact Statement for the Defense Waste Processing Facility, DWPFEIS, (DOE, 1994), the Reactor Operation Environmental Information Documents, Volumes I and III (WSRC, 1989a, \& 1989b), the SRS Ecology Environmental Information Document, (Wike et al., 1994), and the most recent socioeconomic survey of the six-county SRS area of influence (NUS, 1992) contain additional information on SRS areas and facilities, and the areas surrounding SRS. There has been no discernible change to the SRS since the preparation of the DWPFEIS.

\subsection{SAFETY IMPACTS}

The safety review for the disposal package could be broken down into two parts. The first part would deal with conventional accidents arising from the off-loading activities to support the movement of the disposal package, and the second with the nuclear safety issues associated with the off-loading activities to support the movement of the package.

\subsection{Conventional Safety}

The conventional safety concerns associated with this disposal package movement would revolve primarily around the off-loading of the package from the transport barge. The disposal package, trailer, and tow tractors combined weight of approximately $376,488 \mathrm{~kg}(830,000 \mathrm{lbs})$ increases the potential for an accident. However, the shipping contractor Lockwood Brothers, Inc. is one of the nation's leading experts in the movement of oversized/overweight materials. The potential for an accident during the off-loading of the barge is minimal and all environmental and safety risks have been determined to be minimal in nature.

Once the disposal package was off-loaded it would be driven across the SRS to its final destination at the CNSI facility in Barnwell County. At present there are two routes available for movement of the transport package across SRS. Regardless of the route taken the transport scenario would remain essentially the 
same. In each case the affected section of each SRS road would be closed individually as required by the load position or as required to perform work to span any bridges along the chosen route.

The primary route would follow River Road from the SRS Boat Ramp until it intersected with SRS Road 3. Road 3 would then be taken to Road 5. Road 5 would be followed to Road 6, Road 6 to Road G. And finally Road $G$ to Road 8 . Road 8 would then be taken to the site boundary. Once off of SRS the transport package would follow South Carolina highways to the Barnwell County Facility. The timing constraints associated with the primary transport route would follow the following scenario. SRS Road 3 would be closed for 6 hours and SRS Road 5 (Road 3 to Road 6) would be closed for 30 minutes. SRS Road 6 would be closed in sections: Road 5 to Road C for 45 minutes, Road C to Road F for 1 hour, and Road F to Road 7 for 45 minutes. Road 8 from Road 7 to the SRS boundary Williston Barricade would be closed for 6 hours on the second day of the move.

The alternate route would follow essentially the same route as the primary except that it would turn off of Road 6 onto Road C and then follow this SRS Road until it intersected with Road B. Road B would then be taken across the base of Par Pond to the site boundary. The alternate transport route would take the following scenario: SRS Road 3 would be closed for 6 hours and SRS Road $5(\operatorname{Road} 3$ to $\operatorname{Road} 6)$ would be closed for 30 minutes. SRS Road 6 would be closed for 2 hours. Road $\mathrm{C}$ would be closed for 4 hours. Road B to the SRS boundary Snelling Barricade would be closed for 6 hours on the second day of the move.

Traffic signals at the barricades on SRS Road 3 near SC Highway 125 would be affected. The WSRC Electrical \& Instrumentation crews would be responsible for raising these lines. The SRS Power Department has also been notified about the pending move and would be in contact with South Carolina Electric \& Gas (SCE\&G) concerning their transmission line across SRS Road 6. SCE\&G would be responsible for raising these lines as the load approaches and lowering them after it passes.

In addition to the boat ramp modification, some.SRS bridges would be temporarily modified during the movement to meet the $34.1 \mathrm{~m} \mathrm{(l)} \times 8.25 \mathrm{~m}$ (w) $\times 4.72 \mathrm{~m}$ (h) [112'(l) $\left.\times 27^{\prime} 1^{\prime \prime}(\mathrm{w}) \times 15^{\prime} 6^{\prime \prime}(\mathrm{h})\right]$ and 376,488 $\mathrm{kg}(830,000 \mathrm{lbs})$ truck-trailer combination capacity. All bridge modification would be done above the bridge, therefore, there would be no wetlands impacted during this modification. The actual load of the vehicle would never be placed on SRS bridges, but would be carried instead by the temporary bridge spans place over the SRS bridges by CNSL. As the load approaches the bridge, the contractor would construct the span using I-beams and heavy timbers. After the load passes the bridge, the span would be removed and repair of any damage to the asphalt pavement would be corrected. No damages are expected to occur to SRS bridges as a result of the movement of the disposal package.

The transport trailer which would be used in conjunction with this movement is specially designed and constructed so that the weight of the package is evenly distributed to the 112 wheels of the trailer and tow tractor. This load distribution should prohibit any damage to SRS roads. In the event that some damage does occur, CNSI has agreed to repair any damages.

CNSI would coordinate with Wackenhut Securities, Inc.(WSI), the DOE contractor at SRS for security support services, for security and traffic control of the barge while it is on Federal property. Close planning and coordination, including the movement of traffic signals and power would minimize any traffic effects as a result of the barge movement, thereby further minimizing traffic risks.

\subsection{Nuclear Safety}

A Safety Analysis Report (SAR) was not required for the movement of this disposal package since the transportation is being regulated by the U.S. Department of Transportation (DOT) and not by the Nuclear Regulatory Commission (NRC). CNSI has reviewed CNSY's two structural analyses of the disposal package in order to ascertain the ability of the package to retain its structural integrity under the conditions of transport. The first analysis modeled the package secured to the transport barge, resting on two parallel rows of wooden cribbing. The second modeled the package secured to the transport trailer. Results of these 
reviews concluded that the package does meet the requirements of 49 CFR 173.24 and 173.411 and qualifies as a DOT non-specification, strong tight container for its intended use.

In addition, CNSI has designed two sets of tie-down hardware to secure the disposal package during water and land movements. The first set will be installed at the shipyard and will secure the package to the deck of the barge, with the package resting on two rows of wooden cribbing. Upon arrival at the SRS boat ramp, this set would be removed and replaced by a second set of hardware which would secure the package to the transport trailer. Each set of hardware was designed to conform with 49 CFR 393.102 which require that the aggregate static breaking strength used to secure an article against movement in any direction must be at least 1.5 times the weight of that article. These designs would also be approved by CNSY and SCDHEC.

CNSY estimates that contact dose rates on the surface of the disposal package would not exceed $10 \mathrm{mR} / \mathrm{hr}$. Contamination on the package exterior would not exceed $1,000 \mathrm{dpm} / 100 \mathrm{~cm}^{2}$ Beta-Gamma. Based on an occupational risk factor of $4 \times 10^{-4}$ fatal cancers per person-rem, workers involved with this proposed transport would not be expected to incur any harmful health effects from radiation exposures they receive during normal operations.

The disposal package would contain approximately 5.6 curies of radioactivity. Major isotopes are Cobalt60, Nickel-63, and Carbon-14. No fissile materials would be present, therefore criticality is not a concern. The general contents of the package would include piping, valves, pump motors, tanks, and low density fill material that was previously mentioned.

CNSI would undertake the following precautions during the shipment of the disposal package from CNSY.

- A CNSI Health Physics technician would accompany the disposal package movements.

- Radiation and contamination measurements would be taken prior to the movement to verify CNSY outgoing shipment survey results and during transportation to detect any possible change in dose rates or contamination levels.

- Visual and non-destructive testing of welds associated with the installation of the tie-down hardware and visual inspection of all closure plates and welds on the package.

- Prepare a Transportation Plan which sets forth scope, responsibilities, equipment, procedures, and precautions applicable to the shipment of the disposal package. CNSI would submit this plan to DOE in accordance with the terms of the permit between CNSI and DOE-SR.

Authorization has been requested from SCDHEC to allow the one-time, single trip shipment of the package between CNSY and the CNSI Barnwell facility. Receipt of this authorization would be a prerequisite included in the Transportation Plan. 


\subsection{REFERENCES}

DOE (U. S. Department of Energy), 1991. Intent to Prepare Programmatic Environmental Impact Statement for Reconfiguration of the Nuclear Weapons Complex, Federal Register 56 FR 5590-5596

DOE (U. S. Department of Energy), 1992, Environmental Assessment for DOE Permission for Off-loading Activities to Support the Movement of Millstone Unit 2 Steam Generator Sub-Assemblies Across the Savannah River Site, DOE/EA-0818, Savannah River Operations Office, Aiken, South Carolina.

DOE (U. S. Department of Energy), 1994. Final Supplemental Environmental Impact Statement, Defense Waste Processing Facility, Savannah River Site, DOE/EIS-0082-S, Savannah River Operations Office, Aiken, South Carolina.

NUS (NUS Corporation), 1992. Socioeconomic Characteristics of Selected Counties and Communities Adjacent to the Savannah River Site, NUS Report No. 5234, Savannah River Center, Aiken, South Carolina.

Rogers, V., 1992 Memorandum to P. Harmon, September 18, 1992. Evaluation of Wetland Near SRS Boat Ramp, SRT-ESS-92-0529, Westinghouse Savannah River Company, Aiken, South Carolina.

USN (U.S. Department of the Navy), 1984. Final Environmental Impact Statement, Disposal of Decommissioned, Defueled Naval Submarine Reactor Plants, United States Department of the Navy, Washington, D.C.

WSRC (Westinghouse Savannah River Company), 1989a. Reactor Operation Environmental Information Document, Volume I: Geology, Seismology and Subsurface Hydrology (U), WSRC-89-815 Savannah River Site, Aiken, South Carolina.

WSRC (Westinghouse Savannah River Company), 1989b. Reactor Operation Environmental Information Document, Volume III: Meteorology, Surface Hydrology, Transport and Impacts (U), WSRC-89-817, Savannah River Site, Aiken, South Carolina.

Wike, L. D., Shipley, R. W., Bowers, J. A., Bryan, A. L., Cummins, C. L., del Carmen, B. R., Friday, G. P., Irwin, J. E., Mackey, Jr., H. E., Mayer, J. J., Nelson, E. A., Paller, M. H., Rogers, V. A., Specht, W. L., and Wilde, E. W., 1994, SRS Ecology Environmental Information Document, (U), WSRC-TR-93-496, Westinghouse Savannah River Company, Savannah River Site, Aiken, South Carolina. 


\section{APPENDIX A}

Floodplain/Wetlands Assessment

for

DOE Permission for Off-Loading Activities to

Support the Movement of Commercial Low Level

Nuclear Waste Across the Savannah River Site 


\section{Floodplain/Wetlands Ássessment \\ for \\ DOE Permission for Off-Loading Activities to \\ Support the Movement of Commercial Low Level \\ Nuclear Waste Across the Savannah River Site}

\subsection{DESCRIPTION OF PROJECT}

This Floodplain/Wetlands Assessment is designed and intended to function as an Appendix to the Environmental Assessment for DOE Permission for Off-Loading Activities to Support the Movement of Commercial Low Level Nuclear Waste Across the Savannah River Site (DOE/EA-1009). As such a detailed description of the proposed action may be found in that document.

\subsection{EFFECT ON FLOODPLAIN/WETLANDS}

\subsection{Floodplain Assessment}

The proposed site to be reviewed under this Floodplain/Wetlands Assessment is in a well drained floodplain of the Savannah River. The site is currently serving in the capacity of an established and operating boat ramp on the South Carolina side of the Savannah River. The proposed site which is subject to this assessment is a government owned and operated plot of land on the Savannah River Site (SRS). Accordingly, modification of this site, as described in the EA, represents no potential effect on the lives or property of the local populace.

There are no threatened or endangered species involved with this activity. The overall benefit of this activity would be to improve the quality, accessibility, and safety of the existing boat ramp. By re-sodding the area the esthetic value and long term viability of the site would actually be improved.

A potential negative aspect of the proposed action is the possibility of erosion from excessive rains or high river flow during the proposed activity. This potential risk may be reduced by installing pilings at the water line of the boat ramp where the cutting edge of the Savannah River bends inward towards the ramp. The soil material at the subject location is classified as Udortheans, which was formed during construction of the Ellenton Dock and the present boat ramp from Shellbluff and Tawcaw soil series. These soils are typically developed in the well drained floodplain of this region. These soils are normally deposited by streams, and are therefore very erosive in nature. Some of the erosive potential may be reduced by re-sodding after completion of the package off-loading operations.

\subsection{Wetlands Assessment}

There would be no impact on the surrounding wetlands as a result of the proposed action. There are no wetlands adjacent to the road leading out of the river (boat ramp), therefore no direct impact to wetlands should occur. There are wetlands about $122 \mathrm{~m}(400 \mathrm{ft})$ northeast of the rivers edge (and the proposed action). To protect this area, a ridge (a compressed soil berm) was formed during the last Chem-Nuclear Systems, Inc. (CNSI) off-loading operation. This ridge prevents the creation of a new outfall which may inadvertently drain the wetlands and also serves to reduce erosion potential associated with this activity. 


\subsection{Positive and Negative Effects}

The only foreseeable negative impact associated with this project is short term in nature. The possibility of sediment run-off, or erosion, which could occur as the result of a storm during the service barge landing and package off-loading activities, has the potential to. result in a temporary localized reduction in the water quality of the Savannah River. This erosion could also inflict some minor damage to the soils along the bank in the proposed area.

The overall result of the proposed activity would be beneficial in nature. The project would provide the SRS with an improved landing facility which could accommodate a broader spectrum of waterborne equipment. This project also has the potential to improve the overall beauty and long term viability of the area through selective re-sodding.

\subsection{ALTERNATIVES CONSIDERED}

Alternatives to the proposed action and mitigating measures to prevent damage to the proposed site are covered in the Environmental Assessment for DOE Permission for Off-Loading Activities to Support the Movement of Commercial Low Level Nuclear Waste Across the Savannah River Site. 


\title{
Finding of No Șignificant Impact and \\ Floodplain Statement of Findings for
}

DOE Permission for Off-Loading Activities to Support the Movement of Commercial Low Level Nuclear Waste Across the Savannah River Site (SRS)

\begin{abstract}
Agency: U. S. Department of Energy
Action: Finding of No Significant Impact and Floodplain Statement of Findings

Summary: The Department of Energy (DOE) has prepared an environmental assessment (EA), DOE/EA-1009, for the proposed granting of DOE permission for offloading activities to support the movement of commercial low level nuclear waste across SRS. Based on the analyses in the EA, DOE has determined that the proposed action is not a major Federal action significantly affecting the quality of the human environment within the meaning of the National Environmental Policy Act (NEPA) of 1969. Therefore the preparation of an environmental impact statement is not required and DOE is issuing this Finding of No Significant Impact (FONSI) and Floodplain Statement of Findings.
\end{abstract}

\section{Public Availability:}

Copies of the EA and FONSI or further information on the DOE NEPA process are available from:

\author{
Mr. A. Ben Gould \\ Director, Environmental Compliance Division . \\ U.S. Department of Energy \\ Savannah River Operations Office \\ P. O. Box 5031 \\ Aiken, South Carolina 29804 \\ Phone: (800) 242-8269
}

Background: Chem-Nuclear Systems Incorporated (CNSI) maintains and operates the low level radioactive waste burial facility adjacent to SRS in Barnwell County, South Carolina. As the operating contractor at the Barnwell Facility, CNSI has accepted an oversize/overweight package from the Charleston Naval Shipyard (CNSY) for disposal. The package would contain only dry, solid, low level radiologically contaminated waste. The contents of the sealed package would consist primarily of the radiologically contaminated portions of a service barge. The barge, commissioned by the United States Navy to service and maintain ships in its nuclear powered fleet, contained both administrative areas and radiologically controlled work areas. The barge has been in an inactive status since the 1960s and is being decommissioned in a joint effort by CNSI and CNSY. CNSI will be responsible for the shipment of the package from CNSY to the CNSI facility. Currently the barge (herein after referred to as the "disposal package") is being prepared by shipyard personnel for transportation and disposal.

A transport barge carrying the disposal package would make landing at the existing SRS boat ramp, the ramp would be modified as needed for the off-loading, and then the disposal package would be off-loaded and shipped via SRS and state roadways to the CNSI facility. 
This EA assesses the potential environmental and safety effects of DOE allowing CNSI to use Federal property (SRS), for off-loading activities needed to support the movement of this oversize/overweight disposal package to the CNSI facility in Barnwell County, South Carolina. This action has no connection to SRS operations and is in no way necessary to support SRS activities.

Proposed Action: The proposed action is for DOE to grant permission to CNSI to modify and use the SRS boat ramp located just north of the TNX Area on SRS to facilitate off-loading and movement of an oversized decommissioned barge containing low level nuclear waste over SRS roads for disposal at the CNSI low level radioactive waste burial facility in Barnwell County, South Carolina. This same barge was used during CNSI's Millstone Steam Generator Project in 1992 and was landed twice at the SRS boat ramp in November and December of that year. Federal permission to use the SRS boat ramp is necessary to enable CNSI to ship the disposal package (decommissioned barge) via waterborne traffic, the safest and most economical means of movement for this huge package. Once off-loaded, the disposal package would be shipped across SRS using CNSI equipment to their final destination in Barnwell County. The proposed action has no connection to. SRS operations and is in no way necessary to support SRS activities.

Alternatives: In the EA, DOE considered the alternative of refusing DOE permission for the off-loading activities (no action) to the proposed Federal action of granting permission to CNSI to modify and use the SRS boat ramp to facilitate off-loading and movement of the disposal package over SRS roads for their disposal at the CNSI facility in Barnwell County, South Carolina.

Alternatives DOE considered in the EA as available to CNSI should DOE choose the above no action alternative of refusing permission were: use of other docking facilities, overland rail movement, and overland road movement. The alternative of using other docking facilities was not a reasonable alternative because there are no other docks on the South Carolina side of the Savannah River that could accommodate oversize/overweight loads of this magnitude, nor are there any Savannah River bridges that could handle the weight should docks on the Georgia side be considered. The width of the disposal

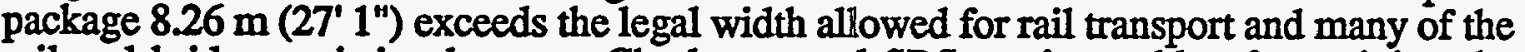
railroad bridges existing between Charleston and SRS are incapable of sustaining the weight of the disposal package. The movement of the disposal package from Charleston, South Carolina to Barnwell, South Carolina via overland highways is an unreasonable alternative because of key highway bridges in route that cannot handle the $376,488 \mathrm{~kg}$ $(830,000 \mathrm{lbs})$ of weight, many underpasses are lower than $6.1 \mathrm{~m}(20 \mathrm{ft})$, numerous low hanging power lines, phone lines, and traffic signals would make this mode of movement economically unfeasible. In addition to the physical obstacles which would have to be overcome, the movement would cause severe traffic obstacles at every point along its route. These means of movement would also represent increased costs and risk of accidents. The chance of a vehicular or rail accident is far greater than the possibility of a mishap by waterborne traffic.

Environmental : The potential environmental impacts of the proposed action of DOE permitting the CNSI off-loading activities to support the movement of the disposal package across SRS were analyzed in the EA and determined to be insignificant. The CNSI modification activities at the SRS boat ramp are minimal in nature and would be reviewed and approved by the U.S. Army Corps of Engineers (COE) as an action which is authorized under Nationwide Permit \#3, prior to any work beginning on the SRS boat ramp. Modifications to the existing SRS boat ramp would include dredging no more than $18.4 \mathrm{cu} \mathrm{m}$ ( $24 \mathrm{cu}$ yds) of sediment below the high water mark of the Savannah River in 
the area $6.1 \mathrm{~m}(20 \mathrm{ft})$ on either side of the boat ramp skid plate to accommodate the 12.2 $\mathrm{m}$ (40 ft) wide transport barge. In addition to the modification and environmental mitigation activities listed above, CNSI would also be responsible for returning the boat ramp above the ordinary high water mark to its preexisting condition. This would be accomplished by; initiating continuing erosion prevention and control activities; and reseeding/re-sodding the area surrounding the boat ramp. In order to maintain compliance with the COE nationwide permit, CNSI has stated that in no case would more than 18.4 cu $m$ ( 24 cu yds) of material be removed from below the Savannah River ordinary high water mark. CNSI would dispose of all sediments and debris, after monitoring and sampling for contamination as necessary, on SRS in an SRS erosion control pit.

In accordance with DOE regulations for compliance with floodplain/wetlands environmental review requirements (10 CFR Part 1022), DOE prepared a recent assessment for the area surrounding the SRS boat ramp for the proposed action and its alternatives. The assessment showed that the floodplain/wetlands within the immediate area would not be affected by the off-loading activities, providing that appropriate erosion control measures were implemented. This Federal action would not threaten a violation of applicable laws or regulations; nor require major expansion or construction of waste facilities such as storage, treatment, or disposal facilities; nor release hazardous substances, pollutants, or contaminants into the environment. This action would take place at an area on the Savannah River previously developed in the 1950s and would not adversely affect environmentally sensitive resources such as historical or archaeological sites, endangered species or their habitat. In addition, an existing programmatic memorandum of agreement with the South Carolina State Historic Preservation Officer describes how SRS cultural resources are to be managed and assessed to determine National Register eligibility. Activities related to this Federal action comply with this agreement.

One potential impact associated with the proposed action would be the possible erosion which could occur as a result of the landing of the service barge and package off-loading operations. Accordingly, CNSI would abide by a Pollution Prevention Plan meeting SCDHEC requirements. These plans typically call for the use of siltation fences, erosion control tarpaulins, and re-seeding/re-sodding to mitigate and control any erosion or sediment run-off. The cumulative effects of these activities have been reviewed and it was determined that they would have no major impact on the surrounding environment. A prior EIS and EA for the construction and operation of a barge landing slip (an action similar to the one proposed in this EA, but on a larger scale) was previously assessed for the SRS boat landing, which includes the boat ramp. The EIS and EA examined SRS and the area surrounding the SRS boat landing and ramp for impact on threatened and endangered species, wetlands, and other environmentally sensitive resources and found that such actions as are discussed in this EA would have "Temporary and minor environmental impacts........". There has been no discernible change in the area surrounding the SRS boat ramp since the preparation of the prior EIS or EA.

Floodplain Statement of Findings: This is a Floodplain Statement of Findings prepared in accordance with $10 \mathrm{CFR}$ Part 1022. A Floodplain/Wetlands Assessment was prepared for those areas impacted by the off-loading activities to support the movement of commercial low level nuclear waste across SRS. The assessment showed that the floodplain/wetlands within the immediate area would not be affected by the off-loading activities, providing that appropriate erosion control measures were implemented. There are no threatened or endangered species involved with this activity. There would be no impact on the surrounding wetlands as a result of the proposed action. There are no wetlands adjacent to the road leading out of the river (boat ramp), therefore no direct impact to wetlands should occur. The only foreseeable negative impact associated with 
this project is short term in nature. The possibility of sediment run-off, or erosion, which could occur as the result of a storm during the service barge landing and package offloading activities, has the potential to result in a temporary localized reduction in the water quality of the Savannah River. This erosion could also inflict some minor damage to the soils along the bank in the proposed area.

The overall result of the proposed activity would be beneficial in nature. The project would provide the SRS with an improved landing facility which could accommodate a broader spectrum of waterborne equipment. This project also has the potential to improve the overall beauty and long term viability of the area through selective resodding.

Determination: Based on the information and analyses in the EA, DOE has determined that the proposed granting of permission to CNSI to modify and use the SRS boat ramp on the Savannah River to facilitate off-loading activities to support the movement of commercial low level nuclear waste across SRSi roads for their disposal at the CNSI facility in Barnwell County, South Carolina does not constitute a major Federal action significantly affecting the quality of the human environment within the meaning of NEPA. Therefore, an environmental impact statement is not required and DOE is issuing this FONSI and Floodplain Statement of Findings.

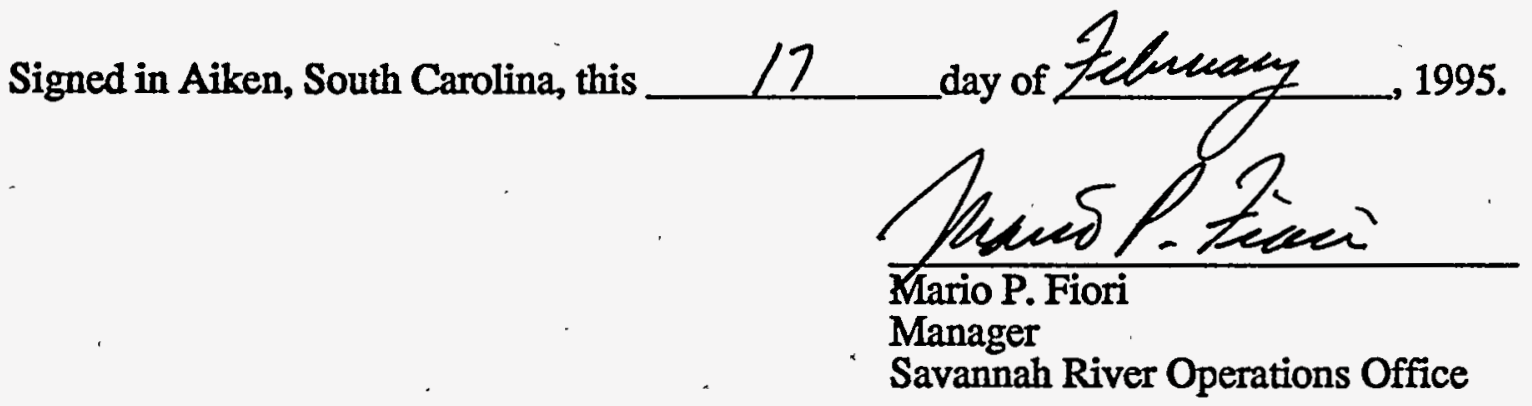

